\title{
SCHOOL DEVELOPMENT MANAGEMENT
}

\section{KATARZYNA BRZYCHCY}

University of Szczecin, Faculty of Management and Economics of Services, POLAND

e-mail: katarzyna.brzychcy@wzieu.pl

RECEIVED
ACCEPTED
JEL
CLASSIFICATION

KEYWORDS

ABSTRACT
18 January 2018

2 September 2018

$\mathrm{M} 12, \mathrm{M} 19$

management, development, environment

Contemporary school faces new challenges. One of them is cooperation with the environment, what should be consistent with the direction of school development. The aim of the article is to discuss the subject of organizational development - schools in the context of cooperation with the environment. The article presents partial research results, the aim of which was to determine the ways of using the school's resources for its development. Research hypotheses assumed, among others, relationship between the level of school development and the number and type of institutions from the environment with which the school cooperates. The research was conducted using two research methods: an interview and a survey. The presented research results are of cognitive nature.

\section{Introduction}

Widely understood development of the organization and undertaking cooperation with the environment become one of the key elements of the modern organization, especially the one that intends to compete effectively with other entities. Schools also fit in with these trends, moreover, Jan Szczepański wrote that "school is a very 
complex, open system, in constant relations with the wider environment and can not exist without these contacts. For they are - if correct - they give direction and meaning to school work" (Szczepański, 1968, p. 38).

Therefore, the environment of the organization, or rather the school's cooperation with the environment may be one of the factors determining the level of school's adjustment to the needs of the labor market. With rapid development, determining the function of science. Speaking of life-long activities (Juśko, Wieczorek, 2016, p. 110):

- educational changes in their evaluation both in the local environment as well as in the national and European or even global,

- the state's educational policy (the process of reforming the education system, the quality of educational law),

- local environment (demography, condition of the local economy, social development strategy of local selfgovernment, education market),

- people who create a school, their system of values and attitudes, qualifications and motivations,

- organizational and managerial skills at school, the leading body, access to financial resources, material resources.

All these factors have a significant impact on the development of the school, but what seems to be the most important is the human resources building the organization. Their role is huge, but research shows (BednarskaWnuk, 2011, pp. 126-127) that manners of human resources management require changes, because the tools used by school directors differ from the standards used by other employers.

The article is a theoretical and empirical. The article focuses on two issues: the human resources of the school, and more specifically their attitudes, involvement that contributes to the development of the school and the creation of cooperation between the school and its surroundings. The issue presented here was based on my own partial research.

\section{School as an organization}

The term „organization” means an institution, (...) or an organizing process, by which one understands the way of arranging and assigning work to members of an organization in order to be able to achieve its assumed goals efficiently" ( Białasiewicz, 2008, p. 15). The school undoubtedly is an organization that has a long tradition, from which it derives good practices and experiences. Despite this, the school requires constant reforms (Szyszka, 2010, p. 272) allowing for better functioning and fulfilling its educational role. Aspects of a well-organized school and the criteria for its organizational evaluation are (Olejniczak, Pielachowski, 2004, p. 49):

a) area of ethical values as the basis for the social mission of the school - refining its own system of ethical values, the code;

b) quality area - high quality of services offered to each student - creation of a system by the school of quality assurance, testing and control of this quality as well as its measurement and evaluation;

c) the area of efficient management or making decisions - own, good rules and decision-making procedures, access to sources of necessary information, formal respect (in accordance with the law) of decisions made, knowledge of criteria and form of efficient operation;

d) area of cooperation with the local environment - cooperation, gaining support from citizens and environmental institutions; 
e) development area - improvement of conditions for continuous development of the student, development and implementation of the school development program, motivating system, and modernization of infrastructure.

The abovementioned areas invoke in a direct or indirect way the aforementioned issues of the school's environment (item 4) as well as the development of the school focused on the development of the child on the one hand, and on the development of the teacher on the other (point 5). Both saved points and others are interrelated and create synergy. Capacity building is largely based on cooperation with the environment undertaken by teachers. All the previously indicated criteria are created to a different extent by drawing on the experience and resources of the organization that constitute the school's environment. However, it is important that the relationships with the environment are effective for the school as an organization and its human resources - students and teachers.

\section{Methodology of research}

The presented research results are part of a wider study, the main theme of which was the management of the school as an organization. The research process focused on the resources of the school, how to acquire and use them. In the research work, answers to two key research questions were sought: how are the school's resources as an organization built? and how are they used to build internal and external relations of the organization? At the same time, a diagnosis was made regarding the directions of school development based on on undertaken participation in educational projects, as well as joint activities with school environment institutions. The research was carried out in 30 primary and secondary schools of the Gdańsk poviat. The research was carried out using two research tools: an interview questionnaire and a questionnaire. In the period from June 2017. until November 2017. the questionnaire was completed by 120 teachers, including representatives of the management. Interviews were conducted with 30 teachers. As part of the research, a thorough analysis of 10 schools was carried out. Selected areas of analysis and its results in relation to secondary school will be presented below.

\section{Case study}

The secondary school was established at the beginning of the 20th century as a result of the efforts of academic teachers. It has a cultivated tradition and is one of the most prestigious high schools. The school employs 94 teachers, including teachers with a professor's degree. In the research community, it is one of the most prominent schools. In the Perspectives rankings, it is in the first hundred, while in the Pomeranian Voivodship it is in the first 10 (Jubileuszowa..., 2018). The results of surveys and interviews supported, among others, an analysis of strengths and weaknesses is presented in Table 1. The results show a paradox that the team of the teaching staff noticed. The variety of activities undertaken at school is on the one hand regarded as a strong side that "attracts" candidates to school, but is also perceived as a weakness and a threat. Attention is drawn to the fact that every opportunity is used that seems interesting from the point of view of school functioning. This, however, distracts and does not focus on the directions important from the point of view of the school. Anyway, it was pointed out that the weakness of the school is the lack of a leading thematic area. Thus, the school does not specialize in a specific field and area. What's more, it does not go according to the trends and needs of the labor market, which is reflected in the lack of any offer developing technical skills and enriching knowledge in the areas of mathematics, computer science and physics. This is what teachers themselves pay attention to, parents confirm - all members of the parents' council notice the necessity to prepare an offer developing technical skills. 
It is worth emphasizing that the participants of the research, the chances for the development of the school, see in cooperation with the school's environment, in a special way with entrepreneurs. However, when asked about specific profiles of employers, they claimed, first of all, that it does not matter ( $89 \%$ of respondents at school), it is important to show that the school has close contact with employers. Previous activities undertaken jointly with entrepreneurs concerned co-financing for student trips and organized events of various types at school (70\%), awarding prizes in competitions (54\%). Unfortunately, none of the teachers said about additional subject activities, or classes developing social competences or entrepreneurship, so desirable today (Strategie..., 2015), participation in the development of classes or teaching programm. This shows that despite the existing cooperation with the environment, the school does not fully use the resources of the environment. An additional contribution to this is the lack of a career counselor at school, whose presence could be a kind of link between the labor market - the natural environment and the decisions taken at school. Current information on trends that take place on the labor market and the reaction of universities and other high schools may constitute a valuable source of knowledge affecting the school's activities. The reason why the school does not show interest in this subject, despite the fact that teachers (91\%) say that they know and observe the situation on the labor market, is the interest in learning at the school of future students. Every year, the school notes that 2-3 candidates apply for one place at school. It is not motivating to undertake, through the pedagogical group, broader activities updating the school's offer, and thus contributing to the school's development.

Table 1. SWOT analysis

\begin{tabular}{ll}
\hline \multicolumn{1}{c}{ Strengths } & \\
\hline - good team, & Weaknesses \\
- team involved, & - no gymnasium, \\
- variety of activities, & - no leading thematic area, \\
- very good position in the city, & - communication of the pedagogical team, \\
- openness to new ones, & - lack of sufficient psychological and pedagogical support, \\
- high competences of the staff, & - the so-called. school clearance, \\
- the best students apply for a place at school & - lack of career counseling, \\
& - lack of legal support, \\
& - the quantity does not equal the quality \\
\hline \multicolumn{1}{c}{ Opportunities } & \\
\hline - perspective for development, & Threats \\
- reform of education, & - victims of their own success, \\
- the possibility of developing technical majors, & - reform of education, \\
- involvement of students and parents, & - routine and laurels, \\
- EU and national projects, & - market trends, \\
- inflow of new people to the school team, & - conflict of interest \\
- cooperation with the environment, & \\
- cooperation with local business, & \\
- support for the organizational unit - the city council, & \\
- Research Institute in Education & \\
\hline
\end{tabular}

Source: own study based on workshops with teachers.

The presented sleep is not conducive to the development of the school, the surroundings and the school's clients are not a stimulus for purposeful actions and reflection on the direction of the school's development. Teachers see the reasons for the fragmentation of undertaken initiatives and their dissipation in the overloaded program and 
it is difficult to do something additional (48\%), sometimes they carry out additional activities, but this is because I do not want to get away from others (33\%), not an initiator of activities there are students who sometimes come with something (15\%). There were also such statements: I am carrying out additional classes - I encourage students to participate in competitions or programs, projects, if they take the initiative, I also have to prepare myself for them and do something more than I have done so far $(21 \%)$. Teachers say they do not have time to develop their own, because the school is not working well, and it is known that "the fish is spoiled from the head" (30\%). As areas for improvement, they indicated the quality of the school team's work:

- timely and correct completion of school documentation (30\%),

- elaboration of procedures and standards for the school's operation (preparation of document templates) $(32 \%)$,

- planning activities in advance (student outputs, organized events at school) (23\%),

- delegation of tasks by the school management (15\%),

- raising the professional qualifications of all employees and using the knowledge and skills acquired (17\%),

- use of all communication channels (56\%).

The answers presented above focus primarily on the organization of the school. Issues related to the timeliness of the work performed or the enforcement of the acquired knowledge on training and meetings remains at the discretion of the school head. However, it is the teacher's responsibility to introduce new tools and areas of student development. Here, they see the need to improve the functioning of the educational and educational areas of the school by:

- improving safety at school (78\%),

- maintaining a high level of the results of the secondary school-leaving examination (69\%),

- establishment of a school scientific/educational council (40\%),

- providing classes in the field of vocational counseling (38\%),

- extending the school's offer to mathematics and IT (18\%).

Teachers at school do not indicate their attitudes and their commitment to school development. Both earlier, when they addressed organizational issues, as well as focusing on educational and upbringing issues, they focus on general school matters. They also do not indicate their role in the process of improving the school's offer, on the contrary they focus on their subjects and are not in favor of increasing the number of hours of subjects they do not teach.

The area of cooperation between the school and the surroundings is very rich (Table 2). The school cooperates with universities, other schools in the country and abroad. He undertakes charity activities that arouse students' sensitivity. Analyzing all the institutions that were indicated, it can be said that these are institutions and organizations that are rather common in cooperation with schools. Therefore, these are not special activities and relationships that make it possible to distinguish a school from other schools.

Teachers asked about what would foster school development were unable to indicate the answer. The question was difficult for them or they did not want to indicate answers so as not to bear the consequences of the answer given in the future, if the solutions proposed in the result were implemented. It is worth emphasizing that when asked about financial resources for training, teachers did not have any objections. The school management, in turn, claimed that the funds are not used because teachers do not report the need to raise their qualifications. Most often, financial resources are earmarked for group training of pedagogical councils. The level of motivation is 
Table 2. Areas of school's cooperation with the environment and activities conducive to cooperation

\begin{tabular}{ll}
\multicolumn{1}{c}{ Cooperation with the environment. } & Activities conducive to development \\
\hline - universities: university, polytechnic, WSE, WSH, WSPS, & - good contacts at different levels of the student-teacher-teacher- \\
- schools from Great Britain, & teacher-school management relationship, \\
- travel agencies, & - work in subject teams, \\
- Regional Examination Commission, & - the involvement of people in various types of charitable activities at \\
- Noble Package, & school, \\
- animal shelter, & - cooperation with the Parents Council, \\
- counsel parents, & - praise and prizes for participation in training and developing \\
- House of Culture, & workshops. \\
- police, & \\
- Municipal Police, & \\
- Polish-German Youth Cooperation, & \\
- Embassy of Spain, & \\
- Institute for Research on Education, & \\
- District Chamber of Legal Advisers & \\
\hline
\end{tabular}

Source: own study based on workshops with teachers.

low among teachers, and the proposed tools that the director has at his disposal are not enough. The attitude that characterizes most of the pedagogical group (76\%) can be described as „having peace of mind.” Asked about the forms of motivation that would help to encourage teachers to work almost unanimously said that the funds (89\%). The others did not have the opinion (4\%). Only a few people pointed out (7\%) pointed to non-financial motivators of co-financing for sports cards, co-financing for cultural events, equipment with personal equipment (telephone, laptop).

\section{Conclusions}

Schools like any organization require development, especially since its main task is to educate young generations and prepare them for adult life. The article presented a small fragment of the school's research results, which is perceived in its environment as one of the prestigious schools. What the research results show, as an organization requires changes, because it seems to go on the so-called "Wave" of good opinion developed in earlier years. However, the way it functions, its participants' approach and tools in the hands of the management team need to be verified.

First of all, the directions of the school's development should be verified and clearly set up, and discussed with the members to gain the consent of all participants in the organization. Second, prepare a plan for introducing strategic actions indicating the next steps and tasks to be performed at all levels of cooperation with the environment and organization. It is worth deciding on the essence of the relations being undertaken and the consequences of this cooperation. Strengthening cooperation in a given field with specific expectations of all parties has a chance to be perceived as a benefit for all parties of the school and institutions from its environment. In addition, relationships can take on the nature of longer cooperation, and thus the brand and identification of mutual needs and expectations in the wider scope of education and the labor market.

Undoubtedly, activities that activate the environment, but above all, the members of the organization must be secured by their conviction about the legitimacy of the actions taken. This is a difficult undertaking due to the longterm nature of the enterprise. This in turn convinces us that the incentive system needs to be supplemented with tools commonly used in the business sphere. This has financial implications, which means that another research 
question should be posed about the role of a public school as an evolving organization that effectively shapes its relations with the environment. To what extent should it be based on subsidies, and how much should it be a selffinancing unit. How much is it able to implement solutions characteristic of a developing organization.

This article and research do not exhaust the topic, on the contrary they arouse reflection, which can be satisfied by continuing the research process.

\section{References}

Bednarska-Wnuk, I. (2011). Efektywność zarządzania zasobami ludzkimi w placówkach edukacyjnych. Zarządzanie Zasobami Ludzkimi, 3-4, 117-127.

Białasiewicz, M. (2008). Podstawy nauki o organizacji. Warszawa: PWE.

Jubileuszowa gala rankingu liceów i techników Perspektywy 2018 (2018). Retrieved from: http://www.perspektywy.pl/portal/index.php? option=com_content\&view=article\&id=3699:metodologie-rankingu-szkol-ponadgimnazjalnych-2018\&catid=237\&ltemid=444.

Juśko, E, Wieczorek, I. (eds.). (2016). Wybrane aspekty wykonywania zadań oświatowych przez jednostki samorządu terytorialnego. Łódź: Wydawnictwo Regis.

Olejniczak T., Pielachowski J. (2004). Nadzór pedagogiczny i organizacyjny nad szkołami i placówkami oświatowymi. Poznań: Empi².

Strategie i dokumenty programowe (2015). Retrieved from: http://psz.praca.gov.pl/wyniki-wyszukiwania/rezultat-wyszukiwania/?p_p_ id $=101 \&$ p_p_lifecycle $=0 \&$ p_p_state $=$ maximized\&p_p_mode $=v i e w \& \_101 \_$struts_action $=\% 2 F a s s e t \_p u b l i s h e r \% 2 F v i e w \_$ content\&_101_assetEntryld=15276\&_101_type=content\&_101_groupld=10240\&_101_ur|Title=15272-strategie-i-dokumentyprogramowe.

Szczepański, J. (1968). Podstawowe pojęcia socjologii. Warszawa: PWN.

Szyszka, M. (2010). Edukacja w Polsce - konieczność reform i nowe wyzwania. Roczniki Nauk Społecznych, 2 (38), 255-274.

Cite this article aS: Brzychcy, K. (2018). School development management. European Journal of Service Management, 3 (27/2), 57-63. DOI: 10.18276/ejsm.2018.27/2-07. 